\title{
Preliminary Study on the Location Selection of Microalgae Cultivation In Nusa Tenggara Region As A Potential Feedstock For Bioavtur
}

\author{
Rr. Citra Permata Kusuma Anggraini ${ }^{1, *}$, Nugroho Adi Sasongko ${ }^{2,3}$, Yanif Dwi Kuntjoro ${ }^{2}$ \\ ${ }^{1}$ Master Program of Energy Security, Faculty of Defense Management, Indonesia Defense University, Bogor - Indonesia \\ ${ }^{2}$ Department of Energy Security, Faculty of Defense Management, Indonesia Defense University, Bogor - Indonesia \\ ${ }^{3}$ Center of Energy Technology and Chemical Industry, The Agency for Assessment and Application of Technology (BPPT), Indonesia
}

\begin{abstract}
NTT is a province located in strategic areas between Bali and South Sulawesi which has economic growth $5,08 \%$ in 2016 . This causes air transportation in NTT to grow rapidly so the need for avtur is increased by $6 \%$ per year. To meet the needs of avtur in NTT would require energy diversification with bioavtur development in which one of them comes from microalgae. The content of lipid and hydrocarbon in microalgae can be used as a source of bioavtur feedstock. The suitability of location for cultivation will influence the success of microalgae cultivation that will be used as a source of bioavtur feedstock. The purpose of this research is to choose the best location for microalgae cultivation in NTT by AHP method. The criteria used in this research are nutrient, water and technology. Sub criteria of nutrient elements are coal power plant emission, cement industry emission and synthetic fertilizers, sub criteria from water that is sea water, brackish water and fresh water, while sub criteria of technology are Photobioreactor, Open Raceway Pond and membrane. The result of AHP analys is shows the selection of microalgae cultivation location in Kupang with the weight of 0.308 , with the source of nutrient derived from coal power plant emission, the type of water used is sea water and the technology used is Photobioreactor. Microalgae species used were Nannochloropsis $s p$ with a lipid content of 31-68\%. Based on the author assumption, microalgae have the productivity for bioavtur manufacture which amount of $24.489 \mathrm{~kL} / \mathrm{ha} / \mathrm{yr}$. That can be used to meet the needs of $2 \%$ avtur in NTT which amount of $1.052,22 \mathrm{~kL} / \mathrm{yr}$ and the area requirement for microalgae cultivation is 2,14 hectare.
\end{abstract}

\section{Introduction}

\subsection{General}

The province of East Nusa Tenggara is a provincial archipelago with 1.192 islands in total, with land area $47.931,54 \mathrm{~km} 2$ [1]. NTT is one of the provinces that has the most number of airports in Indonesia, to date there are 14 airports in operation. NTT has economic growth $5,18 \%$ in 2016[2]. As a developing region, many tourists who come to NTT using air transportation causing avtur demands to increase by $6 \%$ per year [3]. The government requires the use of bioavtures beginning in 2016 with a $2 \%$ mixture that could reduce dependence on imports while reducing air emissions resulting from exhausted fumes[4]. Microalgae have high lipid content, are easy to cultivate, produce high biomass and do not compete with food commodity so it can be developed as biofuel [5]. The location for microalgae cultivation is a major factor to be considered in the effort of providing bioavtur feedstock. In NTT there are 3 developing regions namely Kupang, Ende and Labuan Bajo which seen from the increase of flight passenger number in April 2017 are El
Tari airport 53,52\%, Komodo $12,34 \%$ and Ende 6,17\% [6]. NTT has many tourism destination such as Komodo island, Kelimutu Lake, Diving spot in Labuan Bajo, and soon. NTT government has agenda to improve the infrastructure one of them is transportation sector. NTT has the best weather to cultivate microalgae as a bioavtur feedstock. Kupang has annual relative humidity $72,1 \%$, rainfall 1144,89 $\mathrm{mm}$ and sun radiation 22,92 20,76 $\mathrm{MJ} / \mathrm{m}^{2} / \mathrm{d}$. Ende has annual relative humidity $76 \%$, rainfall $1367,43 \mathrm{~mm}$ y-1 sun radiation $20,76 \mathrm{MJ} / \mathrm{m}^{2} / \mathrm{d}$. That locations is a strategic area in NTT so it can be used as a microalgae cultivation site. Figure 1 is a map of microalgae cultivation location.

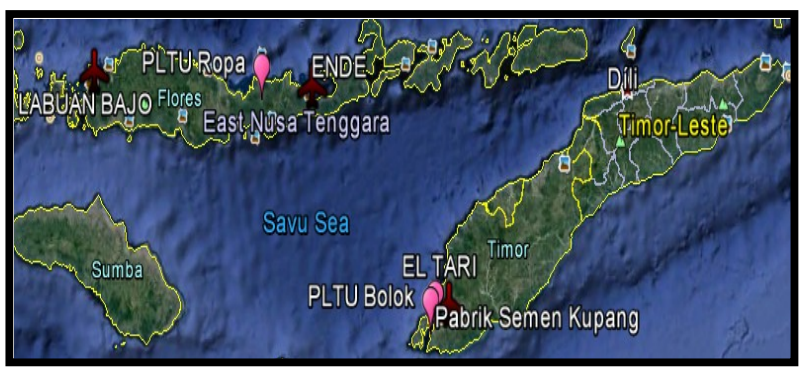

Fig. 1. Map of locations for microalgae cultivation 


\subsection{Objective}

The objective of this research is to choose the best location for microalgae cultivation in NTT by using AHP and to know the potential of microalgae to fulfill $2 \%$ of avtur requirement in NTT.

\section{Methodologies}

Analytic Hierarchy Process (AHP) is developed by Saaty (1980) and then it is used widely as an efficient multi criteria decision making (MCDM) method for ranking alternatives.

AHP is used on three principles :structure of the model, comparative judgment of the alternatives and criteria, synthesis of the priorities [7].

The main steps of AHP are given in the following: First of all, criteria and alternatives of the problem are defined. Then problem is organized hierarchically. The overall goal of this decision making problem is at the highest level and the alternatives are at the lowest level. Criteria and sub-criteria are placed between them [8]. The goal of the problem is located at level 1. Level 2 houses the major criteria. Level 3 houses sub criteria. Finally, the alternatives are located at the last level of the hierarchy. The hierarchy show in the Figure 2.

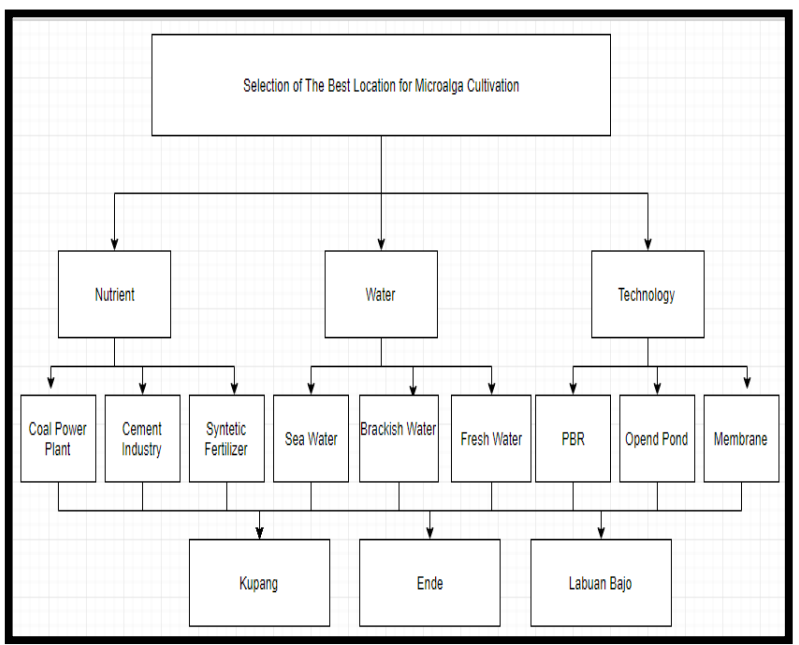

Fig. 2. The Hierarchy Structure for selection of the best location for microalgae cultivation.

After modelling the decision problem as shown above, data were collected from the decision maker by pairwise comparisons. In each level, the criteria are compared pairwise according to their levels of influence and based on the specified criteria in the higher level [7],[9]. These main criteria dan sub criteria for selection the best location for microalgae cultivation are listed in Table 1 . Hierarchy structured with criteria, sub criteria and alternatives location for microalgae cultivation is given in Figure 2. There are three levels in the hierarchy structure for selection for the best location of microalgae cultivation. Saaty's 1-to-9 scale shown in Table 2 is used while comparing $\mathrm{n}$ criteria in the same level.
Table 1. Main criteria and sub criteria for selecting location for microalgae cultivation

\begin{tabular}{|c|c|c|}
\hline Criteria & Sub criteria & Explanation \\
\hline \multirow[t]{3}{*}{ Nutrient } & $\begin{array}{l}\text { Coal power plant } \\
\text { emission }\end{array}$ & $\begin{array}{l}\mathrm{CO}_{2} \text { emission from coal } \\
\text { power plant can be used } \\
\text { as a nutrient for } \\
\text { microalgae growth. NTT } \\
\text { has } 3 \text { coal power plants } \\
\text { there are PLTU Ende } 2 \times 7 \\
\text { MW, PLTU Kupang } 2 \times 15 \\
\text { MW } \\
\text { and PLTU Rote } 2 \times 3 \mathrm{MW} \text {. }\end{array}$ \\
\hline & $\begin{array}{c}\text { Cement industry } \\
\text { emission }\end{array}$ & $\begin{array}{c}\mathrm{CO}_{2} \text { emission cement } \\
\text { factory can be used as a } \\
\text { nutrient for microalgaee } \\
\text { growth. } \\
\text { NTT has } 2 \text { cement } \\
\text { industries in Kupang }\end{array}$ \\
\hline & Fertilizer & $\begin{array}{l}\text { Sufficient nutrient for } \\
\text { microalgae growth. }\end{array}$ \\
\hline \multirow{3}{*}{ Water source } & Sea water & Salinity $30-35 \mathrm{ppt}$ \\
\hline & Brakish water & Salinity 6-29 ppt \\
\hline & Fresh water & Salinity $0-5 \mathrm{ppt}$ \\
\hline \multirow[t]{3}{*}{$\begin{array}{l}\text { Technology } \\
\text { cultivation }\end{array}$} & Photobioreactor & $\begin{array}{l}\text { In closed systems, algae } \\
\text { growth conditions can be } \\
\text { regulated much easily and } \\
\text { precisely by engineers. } \\
\text { Photobioreactor are also } \\
\text { optimized to maximize } \\
\text { algae cultivation. }\end{array}$ \\
\hline & $\begin{array}{c}\text { Opend Raceway } \\
\text { Pond }\end{array}$ & $\begin{array}{l}\text { The biggest advantage of } \\
\text { these open ponds is their } \\
\text { simplicity, resulting in } \\
\text { low production costs and } \\
\text { low operating costs. } \\
\text { While this is indeed the } \\
\text { simplest of all the } \\
\text { growing techniques. }\end{array}$ \\
\hline & Membrane & $\begin{array}{l}\text { Growing microalgae on } \\
\text { membrane minimizes } \\
\text { water use and reduce } \\
\text { harvesting cost. }\end{array}$ \\
\hline
\end{tabular}

Table 2. Saaty's 1-9 scale

\begin{tabular}{ll}
\hline $\begin{array}{l}\text { Intensity of } \\
\text { importance }\end{array}$ & \multicolumn{1}{c}{ Definition } \\
\hline 1 & Equal importance \\
3 & Moderate importance \\
5 & Strong importance \\
7 & Very strong importance \\
9 & Extreme importance \\
$2,4,6,8$ & Intermediate values
\end{tabular}

In this research we use 3 experts. After the calculation of is finished pairwise matrix then it is 
continued by the arrangement of pairing matrix for doing normalization of interest level value of each elements on each hierarchy.

Table 3. Pairwise Comparison

\begin{tabular}{|l|l|l|l|l|}
\hline $\begin{array}{l}\text { Criteria/ } \\
\text { Alternative }\end{array}$ & 1 & 2 & 3 & $\mathrm{~N}$ \\
\hline 1 & 1 & $\mathrm{~W} 12$ & $\mathrm{~W} 13$ & $\mathrm{~W} 1 \mathrm{n}$ \\
\hline 2 & $\mathrm{~W} 21$ & 1 & $\mathrm{~W} 23$ & $\mathrm{~W} 2 \mathrm{n}$ \\
\hline 3 & $\mathrm{~W} 31$ & $\mathrm{~W} 32$ & 1 & $\mathrm{~W} 3 \mathrm{n}$ \\
\hline 4 & $\mathrm{Wn1}$ & $\mathrm{Wn} 2$ & $\mathrm{Wn} 3$ & 1 \\
\hline
\end{tabular}

Assessment in comparing between one criteria and the other criteria is independent of each other, and this may lead to inconsistency. Saaty [10] has proved that the consistency index of the ordered matrix can be obtained by the formula:

$$
\mathrm{CI}=(\lambda \text { maks-n) } /(\mathrm{n}-1) \ldots
$$

Where:

\section{$\mathrm{C} \mathrm{I}=$ Consistency index}

$\Lambda$ maks $=$ The largest eigen value of the ordered matrix

The limit of inconsistency is calculated using consistency ratio (CR) that is by comparison of consistency index (CI) with consistency random index value (RI). Consistency ratios can be formulated:

$$
\mathrm{CR}=\mathrm{CI} / \mathrm{RI}
$$

If the CR value is still less than $10 \%$, then the inconsistency of opinion is still acceptable. The following is a list of random inconsistency indexes presented in Table 4.

Table 4. Index list of Random Inconsistency (RI)

\begin{tabular}{|l|l|l|l|l|l|}
\hline $\mathrm{n}$ & 1 & 2 & 3 & 4 & 5 \\
\hline $\mathrm{RI}$ & 0.00 & 0.00 & 0.58 & 0.90 & 1.12 \\
\hline
\end{tabular}

After AHP is finished then it is continued by modeling the productivity of Nannochloropsis sp as a bioavtur feedstock based on its productivity.

\section{Result And Discussion}

Based on the analysis of AHP, the obtained results are in accordance with the following figure.

Based on the above results, it is seen that the water source is the main criteria in the cultivation of microalgae with a weight value of 0.588 . It is then followed by nutrient with a weight value of 0.159 and the last is technology with a weight value of 0.251 .

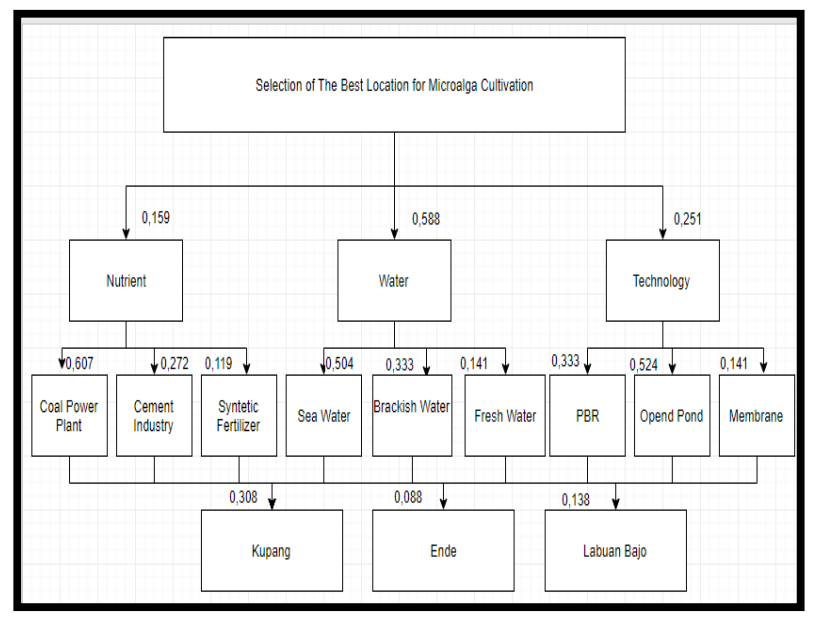

Figure 3. Result of selection for the best location for microalgae cultivation

Water is an absolute requirement of life for microalgae because it is a microalgae living habitat. Water criteria have priority of weighting result on subsea water criteria with value 0,524 . Sea water has a salinity of 30-35 ppt which is a tolerable salinity for microalgae life. Sea water has a natural nutrient content that is used as a source of nutrients for microalgae life. The nutrient content of seawater is chloride (55\%), sodium $(31 \%)$, sulphate $(8 \%)$, magnesium $(4 \%)$, calcium (1\%), potassium (1\%) and the rest (less than $1 \%$ ) comprises of bicarbonate, bromide, borax acid, strontium and fluoride[11]. The three main sources of salt in the ocean are from weathering of rocks on land, volcanic gases and the circulation of hydrothermal vents in the deep ocean.

Nutrient criteria have sub criteria of coal power plant emission with weight value of 0,607 . In general, any source of $\mathrm{CO}_{2}$ can be used for cultivating algae, however some options are more advantageous than others. Using $\mathrm{CO}_{2}(\sim 0.04 \mathrm{w} \%)$ and more must be supplied to facilitate optimal algae growth. The coal power plant's emissions can be used as a source of nutrients for microalgae growth because it contains high $\mathrm{CO}_{2}$ content [12]. Microalgae require $\mathrm{CO}_{2}$ to do photosynthesis so as to produce biomass. Biomass produced by microalgae can be used as a source of biofuel. According to the Ministry of Energy and Mineral Resources Regulation No $32^{\text {nd }}$ 2008 [13] the definition of biofuels is that fuel is derived from vegetable materials or produced from other organic materials. In general, it takes an approximate mass ratio of $2.0 \mathrm{CO}_{2}$ to produce a quantity of algae biomass, e.g., around $2 \mathrm{~g}$ of $\mathrm{CO}_{2}$ are needed to produce $1 \mathrm{~g}$ of ash-free dry algae. $\mathrm{CO}_{2}$ purity is not required in microalgae culture so $\mathrm{CO}_{2}$ emissions from coal power plant can be channelled directly to microalgae cultivation. Another advantage in utilizing $\mathrm{CO}_{2}$ emissions from coal power plants in microalgae cultivation microalgae is that serves as carbon capture so as to reduce $\mathrm{CO}_{2}$ emissions in the air. Water and nutrient management are used to tailor the biochemical composition of the produced algae biomass towards an economically viable biofuels feedstock. 
In the criteria of technology, the sub-criteria of photobioreactor have weighting result of 0.524 . The advantage of using photobioreactor is that the biomass produced is bigger than open pond, the cultivation condition can be regulated by the researcher, with low contamination risk and suitable for microalgae development using $\mathrm{CO}_{2}$ emission as nutrient source.

Based on the results of AHP analysis it is seen that the priority of microalgae cultivation location is in the first position of Kupang city with a weighting of 0.308 . This is supported by the existence of coal power plant located in Kupang. The existence of a coal power plant adjacent to the sea is in accordance with the weighting results stating that sea water is a priority in the selection of water sources. Then the technology used is photobioreactor which is considered more effective for mass scale cultivation of microalgae.

From the results it is assumed that microalgae used is Nannochloropsis sp which is a marine microalgae species with lipid content of $35-68 \%$ of its body so it can be used as source of bioavtur feedstock. Recent studies have reported that marine species Nannochloropsis sp are a potential microalgae for biofuel production owing to the fact that they are capable of producing lipid content as high as $27 \%$ (dry weight) and high biomass productivity [14].The screening of microalgae (Chlorella vulgaris, Spirulina maxima, Nannochloropsis sp., Neochloris oleabundans, Scenedesmus obliquus and Dunaliella tertiolecta) was done in order to choose the best one(s), in terms of quantity and quality as oil source for biofuel production. Nannochloropsis sp. proved to be suitable as raw materials for biofuel production, due to their high oil content (29.0 and $28.7 \%$, respectively) [14].

The National Renewable Energy Laboratory (NREL) has extensive experience cultivating and manipulating microalgae to produce lipids or oils. NREL is now looking to re-establish its microalgae oil research in partnership with oil refiners, with a particular view towards jet fuel production [15].

Bio-jet fuel production by the blending process will be blended with Jet A (or JP5) and diesel to produce biojet fuel blend that can be used on a diesel engine. The US Navy has accepted bio-JP-5 as an alternative to JP-8 fuel [16].

Based on the assumption of microalgae biomass productivity cultivated with photobioreactor that is $24.489 \mathrm{KL} / \mathrm{Ha} / \mathrm{yr}[12,17]$. The need for Avtur in NTT is $52.611 \mathrm{KL} /$ Year. According to the KESDM appeal, the use of bioavtur $2 \%$ starts from 2016, which can be done using microalgae. The need for bioavtures $2 \%$ in NTT is $1.052,22 \mathrm{KL} /$ Year which can be fulfilled from microalgae with productivity of $24.489 \mathrm{~kL} / \mathrm{ha} / \mathrm{yr}$ and the area requirement for microalgae cultivation is 2.14 hectare.

\section{Conclusions}

Based on AHP results it is known that the best location for microalgae cultivation is in Kupang with nutrient source comes from steam power plant emission, type of water used is sea water and technology used is Photobioreactor. The Need of $2 \%$ bioavtur in ENT of $1052,22 \mathrm{~kL} / \mathrm{yr}$ can be met by microalgae with productivity of $24489 \mathrm{~kL} / \mathrm{ha} / \mathrm{yr}$ and the area requirement for microalgae cultivation is 2.14 hectare.

\section{Acknowledgment}

Faculty of Defense Management, Indonesia Defense University.

\section{References}

1. BPS-Statistic of Nusa Tenggara Timur Province, Statistic of Nusa Tenggara Timur Province, Catalog, 511 (2016).

2. H. Bifel, Gubernur: Presiden apresiasi pertumbuhan ekonomi NTT. Available online on http://www.antaranews.com/berita/613176/gubernur -presiden-apresiasi-pertumbuhan-ekonomi-ntt, Accessed on 10th July 2017.

3. Agency For The Assessment and Application of Technology, Outlook Energy Indonesia 2016, Catalog, 108 (2016).

4. The Ministry of Energy and Mineral Resourses, available online on http://ebtke.esdm.go.id/post/2014/08/26/656/pemeri ntah.dorong.pemanfaatan.avtur, Accessed on $10^{\text {th }}$ July 2017.

5. Y.Chisti, Biodiesel From Microalgae, Biotechnology Advances 25, 294-306 (2007)

6. Ulum, M. Penumpang Pesawat Tujuan NTT Meningkat, available online on http://bali.bisnis.com/read/20170603/16/66860/penu mpang-pesawat-tujuan-ntt-meningkat, Accessed on $10^{\text {th }}$ July 2017.

7. M. Dagdeviren, S. Yavuz, N. Kilinc, Weapon Selection Using the AHP and Topsisi methods under fuzzy environment, Expert system with Applications 36, 8143-8151 (2009).

8. L. Wang, J. Chu, J. WU, Int. J. of Production Economics, 107, 151-163 (2007).

9. E. Albayrak, Y. C. Erensal, Journal of Intelligent Manufacturing 15, 491-503 (2004).

10. TL. Saaty, Int. J. Services Sciences, Vol. 1, No. 1 (2008)

11. K. Romimohtarto, and S. Juwana. Biologi Laut. Djambatan, 540 (2007).

12. International Energy Agency, State of Technology Review-Algae Bioenergy. 155 (2017).

13. The Ministry of Energy and Mineral Resources Regulation, No $32^{\text {nd }} \quad 2008$ about Provision, Utilisation And Commerce Biofuel As Other Fuels

14. L. Gouveia and A. C. Oliveira, Journal of Industrial Microbiology and Biotechnology, Vol. 36, No. 2, PP. 269-274, (2009) 
15. A. Darzins, Algal Biofuel Technologies States Biomass/Clean Cities Web Conference, National Renewable Energy Laboratory (2008)
16. M. Elmoraghy, I. H. Farag, International Journal of Engineering and Science, Vol. 1, PP 22-30 (2012).

17. H. Hadiyanto, and M.M.A. Nur. World Applied Sciences Journal, Vol 31 (5), 959-967 (2014) 